\title{
Lavender (Lavandula stoechas L.) essential oils attenuate hyperglycemia and protect against oxidative stress in alloxan-induced diabetic rats
}

\author{
Hichem Sebai ${ }^{1,3}$, Slimen Selmi ${ }^{*}$, Kais Rtibi ${ }^{3}$, Abdelaziz Souli ${ }^{3}$, Najoua Gharbi ${ }^{1}$ and Mohsen Sakly ${ }^{1}$
}

\begin{abstract}
Background: The present study described the phytochemical profile of Lavandula stoechas essential oils, collected in the area of Ain-Draham (North-West of Tunisia), as well as their protective effects against alloxan-induced diabetes and oxidative stress in rat.

Methods: Essential oils samples were obtained from the aerial parts of the plant by hydrodistillation and analyzed by GC-MS. Rats were divided into four groups: Healthy Control (HC); Diabetic Control (DC); Healthy + Essential Oils $(H+E O)$ and Diabetic + Essential Oils $(D+E O)$.

Antidiabetic and antioxidant activities were evaluated after subacute intraperitoneally injection of Lavandula stoechas essential oils ( $50 \mathrm{mg} / \mathrm{kg}$ b.w., i.p.) to rats during 15 days.

Results: The principal compounds detected are: D-Fenchone (29.28\%), a-pinene (23.18\%), Camphor (15.97\%), Camphene (7.83\%), Eucapur (3.29\%), Limonene, (2.71\%) Linalool, (2.01\%) Endobornyl Acetate (1.03\%). The essential oils also contained smaller percentages of Tricyclene, Cymene, Delta-Cadinene, Selina-3,7(11)-diene. Furthermore, we found that Lavandula stoechas essential oils significantly protected against the increase of blood glucose as well as the decrease of antioxidant enzyme activities induced by aloxan treatment. Subacute essential oils treatment induced a decrease of lipoperoxidation as well as an increase of antioxidant enzyme activities.
\end{abstract}

Conclusions: These findings suggested that lavandula stoechas essential oils protected against diabetes and oxidative stress induced by alloxan treatment. These effects are in partly due to its potent antioxidant properties.

Keywords: Lavandula Stoechas, Alloxan, Rat, Essential oils, Antioxidant, Antidiabetic

\section{Introduction}

The Mediterranean diet has been credited with many beneficial effects in the prevention and treatment of cardiovascular diseases [1], including improvement of lipid profiles, reduction in blood pressure, insulin resistance, blood glucose concentration and inflammatory biomarkers [2]. Oxidative stress is believed to be a primary factor in various diseases as well as in the normal process of aging $[3,4]$. Free radicals and reactive oxygen species (ROS) are well known as inducers of cellular and tissue pathogenesis leading to several human diseases such as cancer, inflammatory disorders, atherosclerosis and cardiovascular

\footnotetext{
* Correspondence: slimen.selmi@gmail.com

${ }^{2}$ Département des Sciences de la Vie, Laboratore de Physiologie Animale,

Faculté des Sciences de Tunis, Tunis 1060, Tunisia

Full list of author information is available at the end of the article
}

diseases [5,6]. Cardiovascular diseases are the most common cause of death in the industrialized countries [7]. Many epidemiological and experimental studies have shown that phenolic compounds intake is inversely correlated with atherosclerosis development and related cardiovascular events [8-10]. The beneficial effect of polyphenols is associated with a multitude of biological activities, including antioxidant and free radicalscavenging properties, anti-platelet aggregation and inhibition of vascular smooth muscle cell proliferation. These observations might explain their cardiovascular protective properties [11]. On the other hand, it is now established that hyperlipidaemia represents a major risk factor for the premature development of atherosclerosis and its cardiovascular complications [12]. A logical strategy to prevent against atherosclerosis and reduce the incidence of 
cardiovascular disease events is to target the hyperlipidemia and oxidative stress by diet and/or drug intervention. Lavender (Lavandula stoechas L.) is a medicinal plant largely used in the Tunisian traditional medicine. In fact, this plant is known to protect against headaches, depression and diabetes $[13,14]$. Lavandula stoechas essential oils are rich in monoterpenes and employed for its antimicrobial, antifungal and carminative properties as well as its cosmetic purposes [14-16]. Its leaves and stems are used to prepare decoctions against rheumatism, chill and digestive system diseases [17]. Furthermore, Lavender essential oils are advocated for their use as an antibacterial agent in both early and modern aromatherapy texts $[18,19]$.

Lavender has been extensively phytochemically studied, with limited work on pharmacological aspects and is used by traditional healers for various diseases of the central nervous system, like epilepsy and migraine [20]. It is also used in folk medicine, as an antispasmodic in colic pain and has analgesic, tranquillizer and antiseptic effects [20-23]. Lavender extracts have also positive effects on wound, urinal infections, cardiac diseases and eczema [22]. This species has been also shown to reduce blood sugar levels [13].

In the present study, we studied the protective effect of the lavandula stoechas essential oils against diabetes and oxidative stress induced by alloxan treatment in rat. We also examined their hepatoprotective and nephroprotective effects.

\section{Materials and methods Chemicals}

Alloxan monohydrate, 5,5-dithio bis(2-nitrobenzoic acid) (DTNB), trichloroacetic acid (TCA), $\mathrm{KOH}$, ethanol, ether, bovine serum albumin, orthophosphoric acid 85\%, and $\mathrm{NaCl}$ were obtained from Sigma-Aldrich Co. (Germany).

\section{Plant collection}

Lavandula stoechas (L. stoechas) aerial parts were collected in March, 2010 from the area of Ain-Draham (North-West of Tunisia) and identified by the laboratory of taxonomy in the Faculty of Sciences of Tunis (FST)-Tunisia. The Voucher specimens (No. L101) have been deposited with the herbarium of the Higher Institute of Biotechnology of Béja and also in Department of Biological Sciences, Faculty of Science, Tunisia.

\section{Plant extracts preparation}

The dried aerial parts were submitted to hydrodistillation for 3 hours using Clevenger type apparatus, according to the European Pharmacopoeia (1996). Briefly, the plant was immersed in water and heated to boiling, after which the essential oils were evaporated together with water vapour and finally collected in a condenser. The distillate was isolated and dried over anhydrous sodium sulfate. The oils farctions were stored at $4^{\circ} \mathrm{C}$ until analysis by GC-MS.

\section{Free radical-scavenging activity on DPPH}

The antioxidant capacity of the Lavender essential oils was performed using 2,2-diphenyl-1-picrylhydrazyl (DPPH) radical-scavenging activity as previously described by Grzegorczyk et al. [24]. Briefly, Various concentrations of the essential oils $(20,50,100,150$, and $200 \mu \mathrm{g} / \mathrm{ml})$ were added to $1 \mathrm{ml}$ of $0.1 \mathrm{mM}$ methanol solution of DPPH and incubated at $27^{\circ} \mathrm{C}$ during $30 \mathrm{~min}$. The absorbance of the sample was measured at $517 \mathrm{~nm}$. DPPH radical-scavenging activity (RSA), expressed as percentage was calculated using the following formula:

$$
\operatorname{RSA}(\%)=\frac{A_{\mathrm{DPPH}}-\left(A_{\text {sample }}-A_{\text {control }}\right)}{A_{\mathrm{DPPH}}} \times 100
$$

Ascorbic acid was used as a reference molecule in the same concentration as the test extract.

All the analyses were done in triplicate. The efficacy concentration 50 (EC50) value was defined as the concentration (in $\mu \mathrm{g} / \mathrm{ml}$ ) of the compound required to scavenge $50 \%$ of the DPPH radical.

\section{Gas chromatography-mass spectrometry (GC-MS)}

The essential oils of $L$. Stoechas were subjected to GC-MS analysis using Trace GC ULTRA/Polaris Q (GC-MS, Thermo Electron). The column was a VB-5 (5\% phenyl/ 95\% dimethylpolysiloxane) with film thickness of $0.25 \mu \mathrm{m}$, a length of $30 \mathrm{~m}$ and an internal diameter of $0.25 \mu \mathrm{m}$ helium was used as carrier gas. The GC oven temperature was kept at $50^{\circ} \mathrm{C}$ for $5 \mathrm{~min}$ and programmed to $250^{\circ} \mathrm{C}$ for $3 \mathrm{~min}$ at rate of $4^{\circ} \mathrm{C} / \mathrm{min}$ and programmed to $300^{\circ} \mathrm{C}$ at rate of $25^{\circ} \mathrm{C} / \mathrm{min}$. The injector temperature was set at $250^{\circ} \mathrm{C}$. Split flow was adjusted at $50 \mathrm{~mL} / \mathrm{min}$. MS were taken at $70 \mathrm{eV}$. Mass range was from uma 20 to 350. A library search was carried out using the "Wiley GC/MS Library", Nist and Pmw. The sample was dissolved in Hexane.

\section{Animals and treatment}

Adult male Wistar rats (weighing 220-230 g, 15 weeks old and housed five per cage) were purchased from SIPHAT (Tunis, Tunisia) and used in accordance with the local ethic committee of Tunis University for use and care of animals in conformity with the NIH recommendations. The animals were housed in standard cages $(40 \times 28 \times 16$ $\mathrm{cm})$ under controlled conditions: 12:12-h light-dark, 20$22^{\circ} \mathrm{C}$, food and water are ad libitum. After diabetes induction, rats were divided into 4 groups of 12 animals each:

Group I: non-diabetic rat (control) treated with $\mathrm{NaCl}$ $(0.9 \%$, i.p. $)$ during 15 days.

Group II: diabetic rat (alloxan, $220 \mathrm{mg} / \mathrm{kg}$ b.w.) treated with $\mathrm{NaCl}(0.9 \%)$ during 15 days. 
Group III: non-diabetic rat treated with essential oils (50 mg/kg b.w. i.p.) during 15 consecutive days.

Group IV: diabetic rat (alloxan, $220 \mathrm{mg} / \mathrm{kg}$ b.w. i.p.) treated with essential oils ( $50 \mathrm{mg} / \mathrm{kg}$ b.w., i.p.) during 15 consecutive days.

Twenty hours after the last injection, animals were sacrificed, blood was collected in heparinized tubes. After centrifugation at $3000 \mathrm{~g}$ for $15 \mathrm{~min}$, plasma was processed for biochemical parameter determinations. The liver and the kidney were rapidly excised and homogenized in phosphate buffer saline. After centrifugation at $10000 \mathrm{~g}$ for $10 \mathrm{~min}$ at $4{ }^{\circ} \mathrm{C}$, supernatants were used for biochemical determination of protein, $-\mathrm{SH}$ groups, MDA and antioxidant enzyme activities.

\section{Induction of experimental diabetes}

Experimental diabetes was induced in $12 \mathrm{~h}$ fasted rats by single i.p. injection of alloxan (220 mg/kg body weight) [25] dissolved in citrate buffer (100 mM, pH 4.5). To prevent fatal hypoglycaemia as a result of massive pancreatic insulin release, the rats were supplied with $10 \%$ glucose solution after 6 hours of alloxan administration for the next 24 hours. After seven days, rats with glycemia $\geq 14 \mathrm{mM}$ were selected for the experiment.

\section{Lipid peroxidation}

Lipid peroxidation was detected by the determination of MDA production determined by the method of Begue and Aust [26]. Briefly, homogenates of liver and kidney were centrifuged at $1000 \mathrm{~g}$ for $10 \mathrm{~min}$ at $4^{\circ} \mathrm{C}$ to sediment cell debris and mitochondrial samples. Supernatants were suspended in PBS, $\mathrm{pH}=7.4$, mixed with BHT-TCA (Trichltoracetic acid, Buthylhydroxytoluen) solution (1\%o w/v BHT dissolved in 20\% TCA), centrifuged at $1000 \mathrm{~g}$ for $35 \mathrm{~min}$ and finally mixed with $0.5 \mathrm{~N} \mathrm{HCl}$ and $120 \mathrm{mM}$ TBA (Thiobarbituric acid) in $26 \mathrm{mM}$ Tris and heated in water bath at $80^{\circ} \mathrm{C}$ for $10 \mathrm{~min}$. After cooling, the absorbance of the resulting chromophore was measured at $532 \mathrm{~nm}$. MDA levels were determined by using an extinction coefficient for MDA-TBA complex of $1.5610^{5} \mathrm{M}^{-1} \mathrm{~cm}^{-1}$.

\section{Thiol groups measurement}

Total concentration of thiol groups $(-\mathrm{SH})$ was performed according to Ellman's method [27]. Briefly, aliquots from liver tissue was mixed with $100 \mu \mathrm{l}$ of $10 \%$ SDS and $800 \mu \mathrm{l}$ of $10 \mathrm{mM}$ phosphate buffer (pH 8) and the absorbance was measured at $412 \mathrm{~nm}$ (A0). Then, $100 \mu \mathrm{l}$ of DTNB were added and incubated at $37^{\circ} \mathrm{C}$ during $60 \mathrm{~min}$. After incubation the absorbance of the sample was measured at $412 \mathrm{~nm}$ (A1). The thiol groups concentration was calculated from A1-A0 subtraction using a molar extinction coefficient of $13.6 \times 103 \mathrm{M}-1 \times$ $\mathrm{cm}-1$. Results were expressed as nmol of thiol groups per mg of protein.

\section{Antioxidant enzyme activities assays}

The activity of superoxide dismutase (SOD) was assessed by the spectrophotometric method of Misra and Fridovich [28]. Mn-SOD activity was measured in the presence of $2.0 \mathrm{mM}$ sodium cyanide, an inhibitor of $\mathrm{Cu}, \mathrm{Zn}-\mathrm{SOD}$ [29]. Catalase (CAT) activity was measured by the method of Aebi [30].

\section{Protein determination}

Protein concentration was determined according to Bradford method [31]. Serum albumin was used as standard.

\section{Functional and metabolic parameters Glycaemia assays}

Glucose was measured by the glucose oxidase and peroxidase using quinoneimine as a chromogen. The amount of plasma glucose is related to amount of quinoneimine, which is measured spectrophotometrically at $505 \mathrm{~nm}$ [32].

\section{Assessment of liver function}

Plasma aspartate aminotransferase (AST), alanine aminotransferase (ALT), phosphatase alcaline (PAL), lactate dehydrogenase (LDH) were measured using commercially available diagnostic kits (Biomaghreb, Ariana, TN).

\section{Assessment of renal function}

Plasma urea, creatinine, uric acid and albumin analyses were performed using commercially available diagnostic kits (Biomaghreb, Ariana, TN).

\section{Metabolic parameters}

Plasma total cholesterol (TC), low-density lipoproteincholesterol (LDL), high-density lipoprotein-cholesterol (HDL) and triglyceride (TG) concentrations were measured using commercially available diagnostic kits supplied by Randox laboratories (Ardmore, Northern Ireland, UK).

\section{Statistical analyses}

Data were analyzed by unpaired Student $t$-test and are expressed as mean \pm standard deviation. Data are representative of 12 independent experiments. All statistical tests were two-tailed, and a $p$ value of 0.05 or less was considered significant.

\section{Results}

\section{Chemical composition of the lavender essential oils}

The results obtained by GC-MS analyses of the L. stoechas essential oils (extraction yield $=0.05 \%$ ) are presented in Table 1. Twenty two compounds were identified. The principal compounds detected are: D-Fenchone (29.28\%), $\alpha$-pinene (23.18\%), Camphor (15.97\%), Camphene (7.83\%), Eucapur (3.29\%), and Limonene, (2.71\%) Linalool, (2.01\%) Endobornyl Acetate (1.03\%). The essential oils also 
Table 1 Phytochemical compositions of L. Stoechas essential oils are presented in Table 1

\begin{tabular}{|c|c|c|c|}
\hline No & Components & IR & Compositions (\%) \\
\hline 1 & Tricyclene & 6.137 & 0.51 \\
\hline 2 & a-pinene & 6.720 & 23.18 \\
\hline 3 & Camphene & 7.310 & 7.83 \\
\hline 4 & $\beta$-Phellandrene & 8.500 & 0.10 \\
\hline 5 & $\beta$-Pinene & 8.626 & 0.12 \\
\hline 6 & Delta 3-Carene & 10.554 & 0.11 \\
\hline 7 & Cymene & 11.504 & 0.72 \\
\hline 8 & Limonene & 11.807 & 2.71 \\
\hline 9 & Eucapur & 11.893 & 3.29 \\
\hline 10 & D-Fenchone & 15.835 & 29.28 \\
\hline 11 & Linalool & 16.785 & 2.01 \\
\hline 12 & Camphor & 19.526 & 15.97 \\
\hline 13 & Myrtenol & 23.228 & 0.26 \\
\hline 14 & Endobornyl acetate & 29.122 & 1.03 \\
\hline 15 & Aromad endrene & 33.991 & 0.28 \\
\hline 16 & a-Copaene & 34.809 & 0.28 \\
\hline 17 & Caryophyllene & 37.436 & 0.26 \\
\hline 18 & $\beta$-Selinene & 41.533 & 0.26 \\
\hline 19 & Delta-Cadinene & 43.953 & 0.67 \\
\hline 20 & a -Elemene & 44.434 & 0.12 \\
\hline 21 & Selina-3,7(11)-diene & 44.817 & 0.85 \\
\hline 22 & Delta-gurjunene & 47.730 & 0.20 \\
\hline
\end{tabular}

Twenty two compounds were identified in the essential oils as a result of GC-MS analyze.

IR Retention index.

contained lower percentages of Tricyclene, Cymene, Delta-Cadinene, Selina-3,7(11)-diene.

\section{Antioxidant capacity of the lavender essential oils}

Concerning the antioxidant capacity, we showed in Figure 1 that the radical-scavenging activity (RSA) of $L$. stoechas essential oils and ascorbic acid against DPPH radical increased significantly in a dose-dependant manner. However, L. stoechas essential oils showed an important RSA $(\mathrm{EC} 50=221.43 \mu \mathrm{g} / \mathrm{mL})$ but lesser than ascorbic acid $(\mathrm{EC} 50=87.57 \mu \mathrm{g} / \mathrm{mL})$ used as reference molecule.

\section{Body and relative organs weights}

The weight gain has significantly decreased in alloxaninduced diabetic rats compared to healthy non diabetic animals. Subacute Lavender essential oils administration prevented this decline and protected also against alloxaninduced increase hepatic and renal relative weights (Table 2).

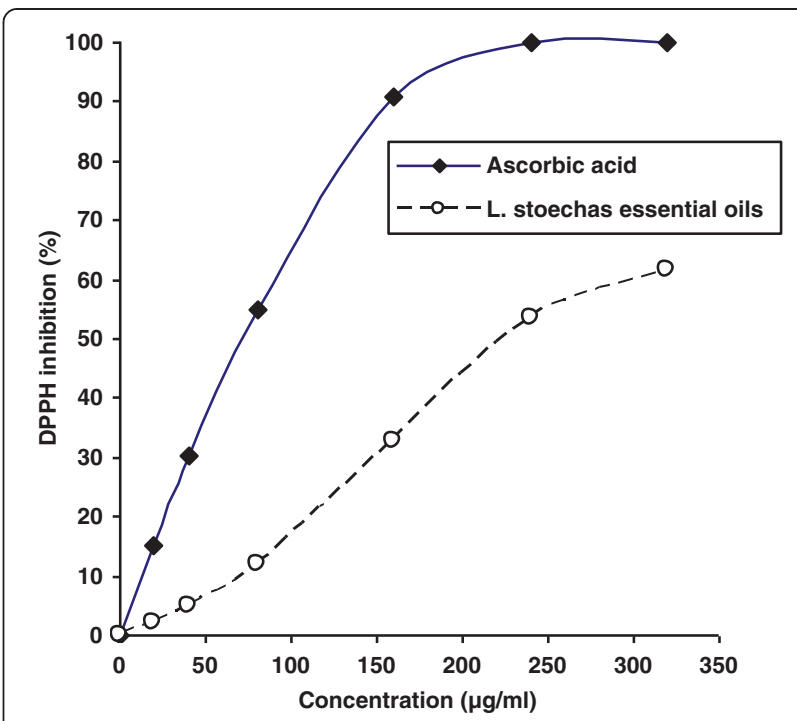

Figure 1 Free radical-scavenging activity of Lavandula stoechas essential oils and ascorbic acid on 2,2-diphenyl-1picrylhydrazyl (DPPH).

\section{Blood glucose level}

Significant increase in blood glucose level was observed in alloxan-induced diabetic rats compared to healthy nondiabetic animals (Table 3). Lavender essential oils treatment corrected significantly this decrease, while essential oils alone had no significant effect.

Effect of lavender essential oils on hepatic and renal lipid peroxidation and thiol groups content

Alloxan-induced diabetes significantly increased liver and kidney MDA level as index of lipid peroxidation and decreased thiol groups content compared to healthy non-diabetic group (Figure $2 \mathrm{~A}, \mathrm{~B}, \mathrm{C}$ and $\mathrm{D}$ ). Treatment with lavender essential oils $(50 \mathrm{mg} / \mathrm{kg} \mathrm{b.w.,}$ i.p.) protected against the lipoperoxidation as well as the decrease of $(-\mathrm{SH})$ groups level induced by alloxan treatment. Lavender essential oils alone had no effect on lipid peroxidation.

\section{Effect of lavender essential oils on liver and kidney antioxidant enzyme activities}

We further looked at the effects of alloxan and Lavender essential oils treatment on hepatic and renal antioxidant enzymes activities. Results presented in the Figure 3A,B,C and $\mathrm{D}$, showed that alloxan administration significantly decreased hepatic and renal antioxidant enzyme activities as CAT, total SOD, cu/zn-SOD and Mn-SOD. Lavender essential oils treatment significantly reversed alloxan-induced antioxidant enzymes depletion. 
Table 2 Subacute effect of Lavandula stoechas essential oils on acute aloxan-induced changes body weight as well as liver and kidney relative weights

\begin{tabular}{lcccc}
\hline & Healthy control & Diabetic control & Healthy + essential oils & Diabetic + essential oils \\
\hline Initial body weight $(\mathbf{g})$ & $227 \pm 2.8$ & $228 \pm 2.3$ & $230 \pm 2.6$ & $227 \pm 2.9$ \\
Final body weight $(\mathbf{g})$ & $241 \pm 2.7$ & $227 \pm 2.4^{\mathbf{a}}$ & $244 \pm 2.4^{\mathbf{b}}$ & $231 \pm 3.1^{\mathbf{b}}$ \\
Liver relative weight (mg/g b.w.) & $33.42 \pm 3.91$ & $62.13 \pm 2.81^{\mathbf{a}}$ & $36.83 \pm 3.45^{\mathbf{b}}$ & $39.51 \pm \mathbf{2 . 2 7 ^ { \mathbf { b } }}$ \\
Kidney relative weight (mg/g b.w.) & $8.7 \pm 0.2$ & $11.13 \pm 0.71^{\mathbf{a}}$ & $8.36 \pm 0.94^{\mathbf{b}}$ & $7.89 \pm 0.49^{\mathbf{b}}$ \\
\hline
\end{tabular}

Animals were treated during 15 days with Lavandula stoechas essential oils ( $50 \mathrm{mg} / \mathrm{kg}$ b.w., i.p.) or vehicle ( $\mathrm{NaCl} 0.9 \%)$ seven days after diabetic induction with alloxan at $220 \mathrm{mg} / \mathrm{kg}$ b.w. Assays were carried out in triplicate.

a $p<0.05$ compared to "Healthy Control" group and ${ }^{\mathbf{b}} p<0.05$ compared to "Diabetic Control" group.

\section{Effect of lavender essential oils on liver and kidney functions}

The exposure of rats to alloxan led to liver dysfunctions as indicated by the of AST, ALT, ALP and LDH activities (Table 3). Concerning kidney function, we showed that alloxan exposure induced an increase of plasma creatinin and urea levels as well as a decrease of albumin and acid uric contents (Tables 2 and 3). Treatment with $L$. stoechas essential oils (50 mg/kg b.w., i.p.) significantly protected against hepatic and renal dysfunctions induced by alloxan treatment.

\section{Effect of lavender essential oils on lipid metabolic parameters}

Table 4 showed that alloxan exposure of rat induced considerable metabolic disorders. Indeed, alloxan treatment of rats significantly increased the TG, TC and LDL plasma contents and decreased the HDL level. Importantly, we showed that $L$. stoechas essential oils supplementation significantly protected against the disturbance of lipid metabolic parameters induced by alloxan.

\section{Discussion}

It was noteworthy that the composition of L. stoechas essential oils in North Africa was in partial agreement with the previous report [33]. Thus, 8-cineole constituted the major constituent of Lavandula essential oils in agreement with previous report [33]. In contrast, other compounds as p-cymen-8-ol, pinocarvone and $\alpha$-terpineol and $\alpha$ terpinen-7-al and fenchone, were not detected in our sample, but were found in other report [34]. Sabinene, which was present at low concentration (1.4\%) in the previous report [34], represented one of the major constituents in our sample (13.89\%). These changes in the essential oils composition are mainly related to the climatic and geographic conditions as well as genetic differences [33]. However, several investigations on the essential oils of various Lavandula species [33,35-37] showed that 1, 8- cineole, linalool, linalyl acetate, fenchone and $\beta$-phellandrene are the characteristic compounds of these plants.

On the other hand, using the DPPH radical-scavenging assay we showed that L. stoechas essential oils presented a higher scavenging capacity which may be related to the presence of phenolic compounds in accord with previous reports [33-37]. However, this antioxidant capacity remained lower than that of ascorbic acid.

Alloxan administration produced diabetes status by destruction of pancreatic $\beta$-cells [38] with changes in metabolic variables as well as kidney and liver functions. We firstly found that alloxan injection decreased body weight gain and increased kidney and liver relative weights. We also showed that alloxan administration increased glycaemia, cholesterol, triglycerides, urea, uric

Table 3 Subacute effect of Lavandula stoechas essential oils on acute aloxan-induced changes in liver and kidney functions

\begin{tabular}{|c|c|c|c|c|c|c|c|c|c|}
\hline & $\begin{array}{c}\text { Glucose } \\
\text { (mM) }\end{array}$ & $\begin{array}{c}\text { ALT } \\
\text { (UI/L) }\end{array}$ & $\begin{array}{l}\text { AST } \\
\text { (UI/L) }\end{array}$ & $\begin{array}{l}\text { ALP } \\
\text { (UI/L) }\end{array}$ & $\begin{array}{l}\text { LDH } \\
\text { (U/L) }\end{array}$ & $\begin{array}{l}\text { Albumin } \\
\text { (g/dl) }\end{array}$ & $\begin{array}{c}\text { Urea } \\
(\mathrm{mmol} / \mathrm{L})\end{array}$ & $\begin{array}{l}\text { Uric acid } \\
\text { (mmol/L) }\end{array}$ & $\begin{array}{l}\text { Creatinin } \\
(\mu \mathrm{mol} / \mathrm{L})\end{array}$ \\
\hline Healthy control & $6.65 \pm 0.66$ & $23 \pm 1.59$ & $39 \pm 2.82$ & $129 \pm 7.1$ & $938 \pm 16$ & $4.72 \pm 0.93$ & $7.64 \pm 0.38$ & $0.28 \pm 0.01$ & $114 \pm 6.7$ \\
\hline $\begin{array}{l}\text { Diabetic } \\
\text { control }\end{array}$ & $15.29 \pm 1.1^{\mathbf{a}}$ & $63 \pm 1.38^{a}$ & $68 \pm 2.13^{a}$ & $179 \pm 6.5^{\mathbf{a}}$ & $1246 \pm 24^{a}$ & $3.15 \pm 0.96^{\mathbf{a}}$ & $10.8 \pm 0.40^{\mathbf{a}}$ & $0.13 \pm 0.02^{\mathbf{a}}$ & $163 \pm 5.9^{a}$ \\
\hline $\begin{array}{l}\text { Healthy + } \\
\text { essential oils }\end{array}$ & $5.17 \pm 0.6^{\mathbf{b}}$ & $21 \pm 1.75^{\mathbf{b}}$ & $37 \pm 3.63^{\mathbf{b}}$ & $148 \pm 6.8^{\mathbf{b}}$ & $916 \pm 13^{b}$ & $5.34 \pm 0.30^{\mathbf{b}}$ & $7.14 \pm 0.35^{\mathbf{b}}$ & $0.28 \pm 0.01^{\mathbf{b}}$ & $126 \pm 6.3^{b}$ \\
\hline $\begin{array}{l}\text { Diabetic + } \\
\text { essential oils }\end{array}$ & $7.81 \pm 0.71^{\mathbf{b}}$ & $32 \pm 1.37^{\mathbf{b}}$ & $43 \pm 2.51^{\mathbf{b}}$ & $155 \pm 9.6$ & $1095 \pm 38^{\mathbf{b}}$ & $4.13 \pm 0.35^{\mathbf{b}}$ & $7.21 \pm 0.89$ & $0.29 \pm 0.01^{\mathbf{b}}$ & $119 \pm 8.4^{b}$ \\
\hline
\end{tabular}

Animals were treated during 15 days with Lavandula stoechas essential oils ( $50 \mathrm{mg} / \mathrm{kg}$ b.w., i.p.) or vehicle ( $\mathrm{NaCl} 0.9 \%)$ seven days after diabetic induction with alloxan at $220 \mathrm{mg} / \mathrm{kg}$ b.w. Assays were carried out in triplicate.

a $p<0.05$ compared to "Healthy Control" group and ${ }^{\mathbf{b}} p<0.05$ compared to "Diabetic Control" group. 


\section{(A)}

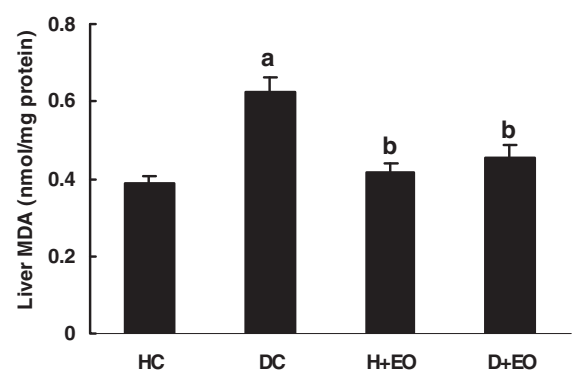

(C)

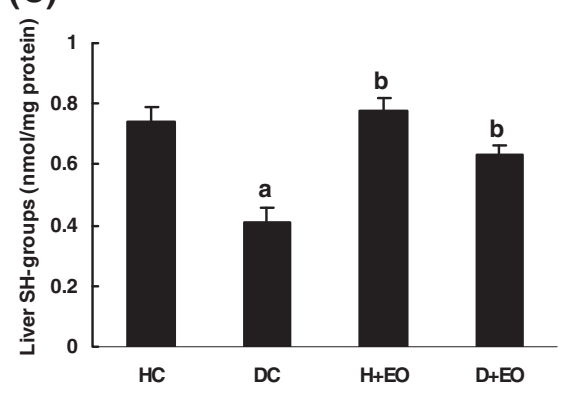

(B)

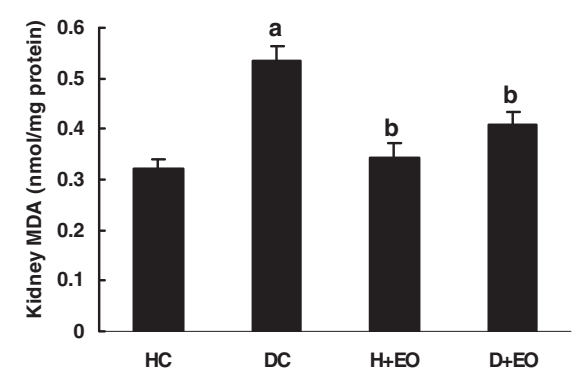

(D)

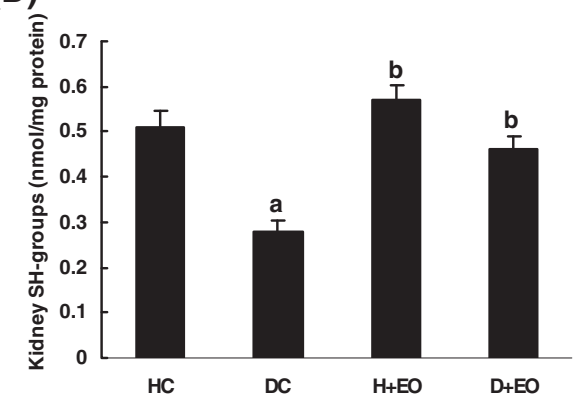

Figure 2 Subacute effect of Lavandula stoechas essential oils on acute aloxan-induced changes in liver and kidney MDA (A and B) and (-SH) groups (C and D) levels. Animals were treated during 15 days with Lavandula stoechas essential oils (50 mg/kg b.w., i.p.) or vehicle ( $\mathrm{NaCl} 0.9 \%)$ sevan days after diabetic induction with alloxan at $220 \mathrm{mg} / \mathrm{kg}$ b.w. Assays were carried out in triplicate. HC: Healthy Control; DC: Diabetic Control; H + EO: Healthy + Essential Oils; D + EO: Diabetic + Essential Oils. "a": $p<0.05$ compared to "Healthy Control" group and "b": $p<0.05$ compared to "Diabetic Control" group.

acid, creatinine, AST, and ALT levels. However, in the alloxan-induced diabetes mellitus, the rise in blood glucose is also accompanied by an increase in plasma cholesterol, triglycerides and urea [39,40].

The diabetogenic effects of alloxan are partly attributed to the specific cytotoxic action mediated by reactive oxygen species generation leading to the damage of large number of $\beta$-cells accompanied by a decrease in endogenous insulin release. However, alloxan-administered rats became hyperglycaemic in a short period of time, followed by a hepatic glucose overproduction [41]. More importantly, we have shown that L. stoechas essential oils decreased blood glucose in alloxan-diabetic rats. L. stoechas oils may exert their antihyperglycaemic effect by potentiating plasma insulin action, secretion or its release from bound form [42]. In diabetic status, lipoprotein lipase is not activated due to insulin deficiency resulting in hypertriglyceridemia and hypertriglyceridemia. This is in agreement with the fact that the glycemia level is the major determinant of total and very low-density lipoprotein cholesterol concentrations [43]. Our data indicated that alloxan-induced diabetic rats presented high levels of plasma urea, uric acid and creatinine, which are considered as significant markers of renal function [44,45]. Treatment with $L$. stoechas essential oils reversed all these parameters to near control levels. The increase of plasma
AST and ALT activities indicated that diabetes may induce hepatic dysfunction as supported by previously findings showing a necrotic liver [46]. Therefore, the increase of transaminase activities in plasma may be mainly due to the leakage of these enzymes from the liver [47]. On the other hand, treatment of the alloxan-diabetic rats with L. stoechas essential oils restored the transaminase activities. These results are in line with those obtained by Ohaeri [48] and illustrate the hepatoprotective effects of lavender against alloxan-induced toxicity.

More importantly, L. stoechas supplementation, protected against alloxan-induced decrease of plasma uric acid concentration as one of the major endogenous water-soluble antioxidants [49], as well as tissue malondialdehyde increase, as marker of lipid peroxidation [50]. We also showed that alloxan administration decreased antioxidant enzymes activities such as SOD and CAT. However, these enzymes are known to be inhibited in diabetic model as a result of non-enzymatic glycosylation and oxidation [51]. These results corroborate previous reports $[51,52]$ indicating the interaction between diabetes and ROS generation. Subacute treatment of alloxn-treted rats with L. stoechas essential oils increased the activities of these enzymes, which might be due to decreased oxidative stress. Previous studies have well shown the richness of lavender extracts as well as 

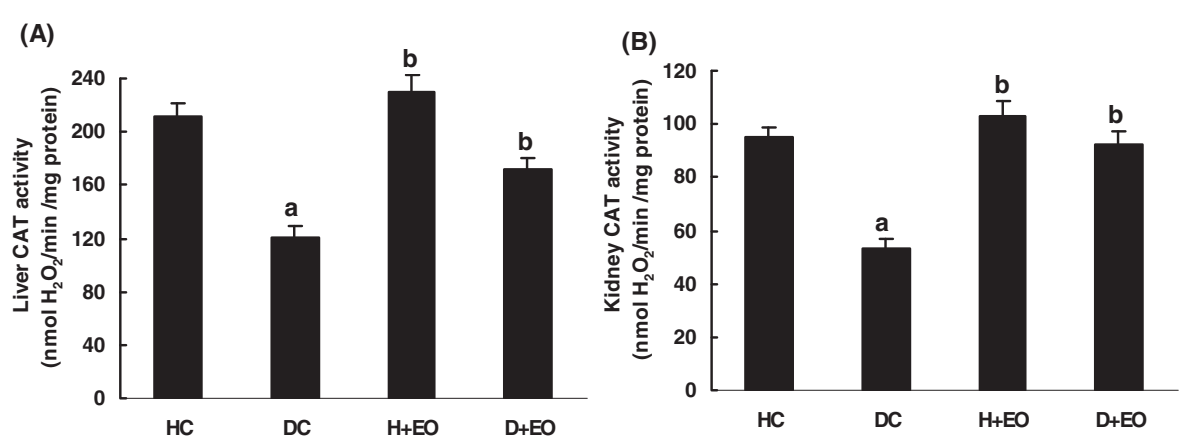

(C)

(D)
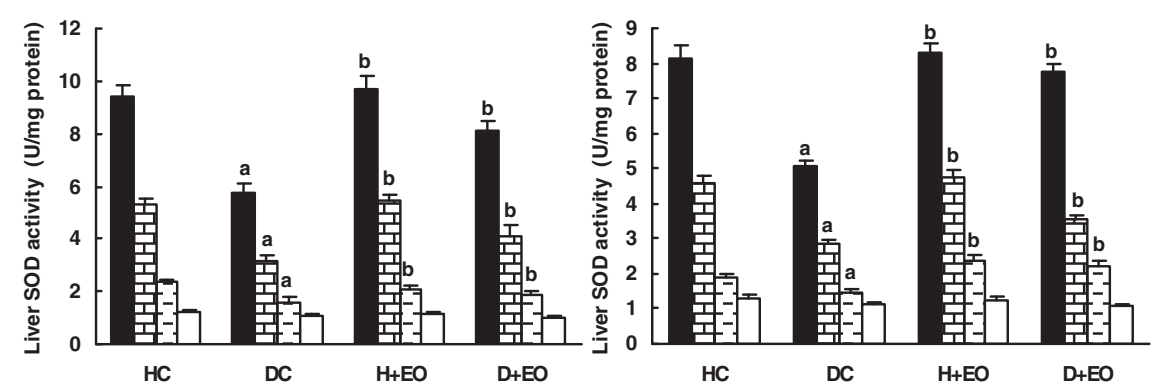

- Total SOD $\square$ Cu/Zn-SOD $\square$ Mn-SOD $\square$ Fe-SOD

Figure 3 Subacute effect of Lavandula stoechas essential oils on acute aloxan-induced changes in liver and kidney CAT (A and B), Total SOD, Cu/Zn-SOD, Mn-SOD and Fe-SOD (C and D). Animals were treated during 15 days with Lavandula stoechas essential oils ( 50 mg/kg b.w., i.p.) or vehicle ( $\mathrm{NaCl}$ 0.9\%) sevan days after diabetic induction with alloxan at $220 \mathrm{mg} / \mathrm{kg}$ b.w. Assays were carried out in triplicate. HC: Healthy Control; DC: Diabetic Control; H + EO: Healthy + Essential Oils; D + EO: Diabetic + Essential Oils. "a": $p<0.05$ compared to "Healthy Control" group and "b": $p<0.05$ compared to "Diabetic Control" group.

essential oils in phenolic compounds [53]. Theses molecules are the primal source of antioxidant ability of this plant, by scavenging free radicals as hydroxyl radical $(\mathrm{OH} \cdot)$ which is the major cause of lipid peroxidation [54]. However, diabetic status is accompanied by high oxidative stress due to persistent and chronic hyperglycaemia leading to the depletion of antioxidant defense system and free radicals generation [55]. Hydroxyl radical $\left(\mathrm{OH}^{-}\right)$reacts with all biological substances and the most susceptible ones are polyunsaturated fatty acids leading to lipid peroxidation [56].
Indeed, increased lipoperoxidation impairs membrane function by decreasing membrane fluidity and changing the activity of membrane-bound enzymes and receptors [57].

In conclusion, our data clearly demonstrated the protective effects of the lavandula stoechas essential oils against diabetes and oxidative stress induced by alloxan treatment in rat. Lavender essential oils decreased kidney and hepatic injuries mainly through their antioxidant properties and played a major role as hepato- and nephroprotector products.

Table 4 Subacute effect of Lavandula stoechas essential oils on acute aloxan-induced changes in lipid metabolic parameters

\begin{tabular}{|c|c|c|c|c|c|c|}
\hline & TG $(\mathrm{mg} / \mathrm{ml})$ & $\mathrm{TC}(\mathrm{mg} / \mathrm{ml})$ & $\mathrm{HDL}(\mathrm{mg} / \mathrm{ml})$ & $\mathrm{LDL}(\mathrm{mg} / \mathrm{ml})$ & TG/HDL & $\mathrm{TC} / \mathrm{HDL}$ \\
\hline Healthy control & $0.66 \pm 0.02$ & $0.72 \pm 0.02$ & $0.19 \pm 0.02$ & $0.21 \pm 0.03$ & 3.47 & 3.78 \\
\hline Diabetic control & $1.28 \pm 0.07^{\mathrm{a}}$ & $0.87 \pm 0.04^{\mathbf{a}}$ & $0.13 \pm 0.02^{\mathbf{a}}$ & $0.34 \pm 0.02^{\mathbf{a}}$ & $9.84^{\mathrm{a}}$ & $6.29^{\mathrm{a}}$ \\
\hline Healthy + essential oils & $0.68 \pm 0.16^{\mathbf{b}}$ & $0.68 \pm 0.03^{\mathbf{b}}$ & $0.14 \pm 0.01^{\mathbf{b}}$ & $0.24 \pm 0.02^{\mathbf{b}}$ & $4.85^{\mathbf{b}}$ & $4.85^{\mathbf{b}}$ \\
\hline Diabetic + essential oils & $0.86 \pm 0.12^{\mathbf{b}}$ & $0.74 \pm 0.04^{\mathbf{b}}$ & $0.16 \pm 0.02^{\mathbf{b}}$ & $0.27 \pm 0.03^{\mathbf{b}}$ & $5.37^{\mathbf{b}}$ & $4.62^{\mathbf{b}}$ \\
\hline
\end{tabular}

Animals were treated during 15 days with Lavandula stoechas essential oils ( $50 \mathrm{mg} / \mathrm{kg}$ b.w., i.p.) or vehicle (NaCl $0.9 \%)$ seven days after diabetic induction with alloxan at $220 \mathrm{mg} / \mathrm{kg} \mathrm{b.w.}$. Assays were carried out in triplicate.

a $p<0.05$ compared to "Healthy Control" group and ${ }^{\mathbf{b}} p<0.05$ compared to "Diabetic Control" group. 


\section{Abbreviations}

ALT: Alanine aminotransferase; AST: Aspartate aminotransferase; BSA: Bovine serum albumin; CAT: Catalase; HDL-C: HDL-cholesterol; LDL-C: LDL-Cholesterol; MDA: Malondialdehyde; PAL: Phosphatase alkalines; SOD: Superoxide dismutase; TC: Total-cholesterol; TG: Triglyceride; LPO: Lipoperoxidation.

\section{Competing interests}

The authors declare that they have no competing interests.

\section{Authors' contributions}

HS and SS performed experiment $s$ and wrote the first version of the manuscript. KR, AS, NG and MS participated in the design of the study, data analysis, and editing of the manuscript. All authors read and approved the final version of the manuscript.

\section{Acknowledgements}

Financial support of the Tunisian Ministry of "Enseignement Supérieur et Recherche Scientifique" is appreciatively acknowledged. We thank Radhouen Mekni for expert technical assistance.

\section{Declaration of interest}

This research received no specific grant from any funding agency in the public, commercial, or not-for-profit sectors.

\section{Author details}

'Laboratoire de Physiologie Intégrée, Faculté des Sciences de Bizerte, 7021 Zarzouna, Tunisia. ${ }^{2}$ Département des Sciences de la Vie, Laboratore de Physiologie Animale, Faculté des Sciences de Tunis, Tunis 1060, Tunisia. ${ }^{3}$ Laboratoire de Nutrition et Physiologie Animale - Institut Supérieur de Biotechnologie de Béja, Avenue Habib Bourguiba - B.P., 382-9000 Béja, Tunisia.

Received: 7 August 2013 Accepted: 21 December 2013

Published: 28 December 2013

\section{References}

1. Walker C, Reamy BV: Diets for cardiovascular disease prevention: what is the evidence? Am Fam Physician 2009, 79:571-588.

2. Martinez-Gonzalez MA, Bes-Rastrollo M, Serra-Majem L, Lairon D, Estruch R, Trichopoulou A: Mediterranean food pattern and the primary prevention of chronic disease: recent developments. Nutr Rev 2009, 67(Suppl 1):111-116.

3. Austin MA, Hokanson JE, Brunzell JD: Characterization of low density lipoprotein subclasses: methodologic approaches and clinical relevance. Curr Opin Lipidol 1994, 5:395-403.

4. Liao L, Starzyk RM, Granger DN: Molecular determinants of oxidized low-density lipoprotein-induced leukocyte adhesion and microvascular dysfunction. Arterioscler Thromb Vasc Biol 1997, 17:437-444.

5. Halliwell B: Free radicals, antioxidants and human diseases; curiosity, cause, or consequence. Lancet 1994, 334:721-724.

6. Aviram M: Review of human studies on oxidative damage and antioxidant protection related to cardiovascular diseases. Free Radical Res 2000, 33:85-97.

7. Wei JY: Age and the cardiovascular system. N Engl J Med 1992, 327:1735-1739.

8. Hertog MG, Feskens EJ, Hollman PC, Katan MB, Kromhout D: Dietary antioxidant Flavonoids and risk of coronary heart disease: the Zutphen Elderly Study. Lancet 1993, 342:1007-1011.

9. Huxley RR, Neil HA: The relation between dietary flavonol intake and coronary heart disease mortality: a metaanalysis of prospective cohort studies. Eur J Clan Nutr 2003, 57:904-908.

10. Sesso HD, Gaziano JM, Liu S, Buring JE: Flavonoid intake and the risk of cardiovascular disease in women. Am J Clin Nutr 2003, 77:1400-1408.

11. Fuhrman B, Aviram M: Flavonoids protect LDL from oxidation and attenuate atherosclerosis. Curr Opin Lipidol 2001, 12:41-48

12. Gomez MJ, Jimenez J, Risco S, Zarzuelo A: Hypoglycaemic activity in various species of the genus Lavandula. Pharmazie 1987, 42:706-707.

13. Gilani AH, Aziz N, Khan MA, Shaheen F, Jabeen Q, Siddiqui BS, Herzig JW: Ethnopharmacological evaluation of the anticonvulsant, sedative and antispasmodic activities of Lavandula stoechas L. J Ethnopharmacol 2000 71:161-167.

14. Cavanagh HMA, Wilkinson JM: Biological activities of lavender essential oil. Phytother Res 2002, 16:301-308.
15. Lis-Balchin M, Deans SG: Bioactivity of selected plant essential oils against Listeria monocytogenes. J App/ Microbiol 1997, 82:759-762.

16. Lis-Balchin M, Deans SG, Eagles ham E: Relationship between bioactivity and chemical composition of commercial essential oils. Flavour Frag J 1998, 13:98-104.

17. El-Hilaly J, Hmammouchi M, Lyoussi B: Ethnobotanical studies and economic evaluation of medicinal plants in Taounate province (Northern Morocco).J Ethnopharmacol 2003, 86:149-158.

18. Lawless J: The Encyclopaedia of Essential Oils. Melbourne, Australia: Element; 1992.

19. Gattefosse RM: Gattefosse's Aromatherapy. Essex, England: CW Daniel; 1993.

20. Nadkarni KM: Indian materia medica p. 730 (3rd ed.). Bombay: Popular Prakashan; 1982

21. Usmanghani K, Saeed A, Alam MT: Indusyunic medicine. Karachi: University of Karachi Press; 1997:273.

22. Benabdelkader T, Zitouni A, Guitton $Y$, Jullien $F$, Maitre D, Casabianca $H$, Legendre L, Kameli A: Essential oils from wild populations of Algerian Lavandula stoechas L.: composition, chemical variability, and in vitro biological properties. Chem Biodivers 2011, 8:937-953.

23. Grzegorczyk I, Matkowski A, Wysokinska H: Antioxidant activity of extracts from in vitro cultures of Salvia officinalis L. Food Chem 2007, 104:536-541.

24. Liu J, Yu Y, Fan YZ, Chang H, Liu HM, Cui Y, Chen Q, Wang R: Cardiovascular effects of endomorphins in alloxan-induced diabetic rats. Peptides 2005, 26:607-614.

25. Begue JA, Aust SD: Microsomal lipid peroxidation. Meth Enzymol 1978, 52:302-310

26. Ellman GL: Tissue sulfhydryl groups. Arch Biochem Biophys 1959, 82:70-77.

27. Misra HP, Fridovich I: The role of superoxide anion in the autoxidation of epinephrine and simple assay for superoxide dismutase. J Biol 1972, 247:3170-3175.

28. Azhar S, Cao L, Reaven E: Alteration of the adrenal antioxidant defense system during aging in rats. J Clin Invest 1995, 96:1414-1424.

29. Aebi H: Catalase in vitro. Meth Enzymol 1984, 105:121-126.

30. Bradford MM: A rapid and sensitive method for the quantitation of microgram quantities of protein utilizing the principal of protein-dye binding. Anal Biochem 1976, 72:248-254.

31. Lott JA, Stang JM: Serum enzymes and isoenzymes in the diagnosis and differential diagnosis of myocardial ischemia and necrosis. Clin Chem 1980, 26:1241-50.

32. Dob T, Dahmane D, Tayeb B, Chelghoum C: Chemical composition of the essential oil of Lavandula dentata L. From Algeria. The Int J Aromath 2005, 15:110-114

33. Pascual TJD, Caballero E, Caballero C, Machin G: Constituents of the essential oil of Lavandula latifolia. Phytochem 1983, 22:1033-1034.

34. Perry NB, Anderson RE, Brennan NJ, Douglas MH, Heane AJ, Mc Grimpsey JA, Smallfield BM: Essential oil from Dalmatian sage (Salvia officinalis L.), variations among individuals, plant parts, seasons and sites. J Agric Food Chem 1999, 47:2048-2054.

35. Pascual TJD, Ovejero J, Anaya J, Caballero E, Hernandez JM: Chemical composition of the Spanish spike oil. PlantaMedica 1989, 55:398-399.

36. Barazandeh MM: Essential oil composition of Lavandula latifolia Medik from Iran. J Essent Oil Res 2002, 14:103-104.

37. Nogueira JMF, Romano A: Essential oils from micropropagated plants of Lavandula viridis. Phytochem Anal 2002, 13:4-7.

38. Szkudelski T: The mechanism of alloxan and streptozotocin action in b-cells of the rat pancreas. Physiol Res 2001, 50:536-546.

39. Cam CM, Cros HG, Serrano JJ, Lazaro R, McNeill HJ: In vivo antidiabetic actions of naglivan, an organic vanadyl compound in streptozotocininduced diabetes. Diab Res Clin Pract 1993, 20:111-121.

40. Pari L, Saravanan G: Antidiabetic effect of cogent $\mathrm{db}$, a herbal drug in alloxan induced diabetes. Comp Biochem Physiol 2002, 131:19-25.

41. Martinez JA, Milagro Fl: Effects of the oral administration of a $\beta 3$-adrenergic agonist on lipid metabolism in alloxan-diabetic rats. J Pharm Pharmacol 2000, 52:851-856.

42. Pushparaj NP, Tan HKB, Tan HC: The mechanism of hypoglycemic action of the semi purified fractions of Averrhoa bilimbi in streptozotocin diabetic rats. Life Sci 2001, 70:535-547.

43. Laakso M: Epidemiology of diabetic dislipidemia. Diab Rev 1995, 3:408-422.

44. Burtis CA, Ashwood ER: Enzymes, Teitz fundamentals of clinical chemistry. 4th edition. Philadelphia, USA: NB Saunders Company; 1996:312-335. 
45. Almdal TP, Vilstrup H: Strict insulin treatment normalizes the organic nitrogen contents and the capacity of urea-N synthesis in experimental diabetes in rats. Diabetologica 1988, 31:114-118.

46. Whitehead MW, Hawkes ND, Hainsworth I, Kingham JGC: A prospective study of the causes of notably raised aspartate transaminase of liver origin. Gut 1999, 45:129-133.

47. Larcan A, Lambert H, Laprevote-Heully MC, Delorme N: Light and electron microscopic study of hepatic lesions in the course of hyperlactatemia in diabetic patients. Diab Metab 1979, 5:103-112.

48. Navarro CM, Montilla PM, Martin A, Jimenez J, Utrilla PM: Free radicals scavenger and antihepatotoxic activity of Rosmarinus. Plant Med 1993, 59:312-314.

49. Estornell $E$, Barber T, Cabo J: Improved nitrogen metabolism in rats fed on lipid-rich liquid diets. Br J Nutr 1994, 71:361-373.

50. Del Rio D, Stewart AJ, Pellegrini N: A review of recent studies on malondialdehyde as toxic molecule and biological marker of oxidative stress. Nutr Metab Cardiovasc Dis 2005, 15:316-328.

51. Al-Azzawie H, Alhamdani MSS: Hypoglycaemic and antioxidant effect of oleuropein in alloxan-diabetic rabbits. Life Sci 2006, 78:1371-1377.

52. Sepici-Dincel A, Acıkgoz S, Cevik C, Sengelen M, Yes, ilada E: Effects of in vivo antioxidant enzyme activities of myrtle oil in normoglycaemic and alloxan diabetic rabbits. J Ethnopharmacol 2007, 110:498-503.

53. Matosa F, Miguela MG, Duartea J, Venânciob F, Moiteirob C, Correiac AID, Figueiredod AC, Barrosod JG, Pedrod LG: Antioxidant capacity of the essential oils from Lavandula luisieri, L. stoechas subsp. lusitanica, L. stoechas subsp. lusitanica $\times \mathrm{L}$. luisieri and $\mathrm{L}$. viridis grown in Algarve (Portugal). J Essent Oil Res 2009, 21:327-336.

54. Kumazawa S, Taniguchi M, Suzuki Y, Shimura M, Kwon MS, Nakayama T: Antioxidant activity of polyphenols in carob pods. J Agric Food Chem 2002, 50:373-377.

55. Kamalakannan N, Prince PSM: Antihyperglycaemic and antioxidant effect of rutin, a polyphenolic flavonoid, in streptozotocin-induced diabetic wistar rats. Basic Clin Pharmacol Toxico 2006, 98:97-103.

56. Memis o'gullar R, Bakan E: Levels of ceruloplasmin, transferin, and lipid peroxidation in the serum of patients with type 2 diabetes mellitus. J Diabetes Complications 2004, 18:193-197.

57. Arulselvan P, Subramanian SP: Beneficial effects of Murraya koenigii leaves on antioxidant defense system and ultra structural changes of pancreatic-cells in experimental diabetes in rats. Chem Biol Interact 2007, 165:155-164.

doi:10.1186/1476-511X-12-189

Cite this article as: Sebai et al:: Lavender (Lavandula stoechas L.) essential oils attenuate hyperglycemia and protect against oxidative stress in alloxan-induced diabetic rats. Lipids in Health and Disease 2013 12:189.

\section{Submit your next manuscript to BioMed Central and take full advantage of:}

- Convenient online submission

- Thorough peer review

- No space constraints or color figure charges

- Immediate publication on acceptance

- Inclusion in PubMed, CAS, Scopus and Google Scholar

- Research which is freely available for redistribution 